\title{
Russiske kvinner i Nord-Norge: fortellinger om soppturer og sovjettid
}

\author{
Tatiana Wara \\ Stipendiat, UiT Norges arktiske universitet
}

\begin{abstract}
Russian Women in Northern Norway: Stories about Mushroom Picking and the Soviet Past

The article portrays and discusses various reorientation practices used by Russian women who have migrated to the Finnmark region in Northern Norway. It draws on participant observation, individual interviews and focus group interviews. The fieldwork revealed that mushroom related activites - picking, talking about, preparing and eating - constitute an important part of a shared Russian heritage accumulated through a communist-era childhood. The article makes particular use of Floya Anthias' concept of translocal positioning. Anthias conceptualizes social positioning as a practice that occurrs within and across both concrete locations and cultural contexts, and is shaped by specific processes of minoritizing and majoritizing. Through the perspective of translocation, and inspired by Merleau-Ponty's phenomenology of the body (1994), this article aims to show how my informants position themselves as Russian women in Finnmark. Based on an analysis of the experiences and practices related to mushrooms, the article argues that migrants' reorientations may fruitfully be viewed as practices that are constituted through the body across time and space.
\end{abstract}

Keywords: mushroom, migration, translocal positioning, Russian cultural heritage, body, belonging, phenomenology

«Syltet sopp er en delikatesse som står på egne bein. (. . ) de kan forvandle et trivielt måltid til en fest» (Jamin-Pasternak 2008: 219, min oversettelse).

Jeg vokste opp i den lille gruvebyen Kirovsk, den eneste byen i Nord-Russland som er lokalisert midt i et fjellmassiv. Det største fjellpartiet heter Kukisvumtsjorr som betyr «Fjellet ved den lange dalen». Jeg har mange herlige minner om barndommens soppturer i denne dalen. Det var en stor begivenhet, og hele familien var sammen hele dagen. En sopptur startet gjerne med at mamma fylte termosene med kakao og lagde nistemat. Da jeg var liten dro vi ut til skogen med buss, etter at jeg ble større kjørte vi egen bil. Mens vi gikk på sopptur snakket mine foreldre med meg om soppen vi fant, og kommenterte deres størrelse og form. Steinsopp var soppens konge, men vi fant også rødskrubb, brunskrubb og mange andre sorter. Etter soppturen dro vi hjem, renset soppen og startet foredlingen. Noen sopper ble marinert, andre ble syltet, noen ble

^Kontaktinformasjon: Tatiana Wara. E-mail: tatiana.wara@uit.no 
stekt og noen ble kokt. Når soppretter sto på bordet, var det fest. Ingen nyttårsaften var uten sopp. De små soppene var betraktet som de aller beste, og ble servert kun ved store anledninger og til ens kjæreste gjester.

I dag bor jeg ikke lenger i Nord-Russland, men i Nord-Norge. Jeg elsker fortsatt sopp, og fortsatt er høstens soppturer viktige for meg. Jeg er ikke alene om å ha det slik. De siste fire årene har jeg jobbet med et prosjekt om kvinnelige migranter fra Russland som har bosatt seg i Finnmark. I denne studien er jeg opptatt av å forstå kvinners reorienteringspraksiser på de nye bostedene i nord gjennom et fokus på deres mobile kropper. På ulike tidspunkt i feltarbeidet dukket sopp opp som et betydningsfylt tema. Jeg har fått servert sopp som deilig tilbehør i festlige lag sammen med mine informanter ved flere anledninger. Uansett hvor herlig hovedrett vertinnen serverer, er det de syltede eller marinerte soppene som vekker den største entusiasmen blant de russiske gjestene. Soppen vekker barndomsminner, skaper følelser og trekker veksler på fortellinger med både erfaringsnære, moralske og kulturelle aspekter. I denne artikkelen vil jeg analysere hvordan mine informanter posisjonerer seg som russiske kvinner i Finnmark gjennom et fokus på soppfortellinger, samt hvordan soppfortellinger kan forstås som en etablering av russiskhet. Som analysene vil vise, skjer dette både gjennom hverdagspraksiser på migrantenes nåværende bosted i Norge, og gjennom refleksjoner over deres sovjetiske barndomsminner.

Høsten 2015 var jeg med på sopptur sammen med noen av mine informanter. Vi plukket, renset, stekte og spiste sopp sammen. Mens vi gjorde dette, fortalte informantene russiske folkeeventyr og refererte til litteraturens fremstillinger av sopp. Mine tanker vandret til min egen barndom i Kirovsk og den lange dalen. Kirovsk er en by som lenge har hatt høgskoler og et bredt kultur- og idrettstilbud, men det er også byen som mine besteforeldre var med å bygge mens de bodde i arbeidsleir, etter å ha blitt sendt dit som politiske straffarbeidere i Stalin-tiden. Disse erfaringer har en betydning for hvordan jeg selv posisjoner meg i møte med mine informanter (Wara 2009). Både i min egen og i mine informanters barndom og voksenliv utgjør det å dra på sopptur, og det å foredle og spise sopp en viktig del av våre russiske tradisjoner, som binder sammen og veves inn i unike fortellinger om levd liv, og som vi har med oss når vi flytter til et nytt sted.

I det følgende analyserer jeg først fortellinger om soppsanking som rekreasjon og matauke og viser at det å servere syltet sopp og andre foredlede soppretter, kan forstås som et symbol på ekte russisk (feminint) vertskap. Videre viser jeg at soppens betydningsfulle posisjon som russisk tradisjonsforvalter kan forstås i lys av migrantenes levde erfaringer fra deres barndom i det gamle Sovjet. Jeg tolker migrantenes reorienterings- eller posisjoneringsprosesser som noe som skapes i relasjoner mellom praksis, kropp, tid og rom (jf. Merleau-Ponty 1994). For å understøtte dette, veksler jeg mellom analyser av datamateriale fra mitt feltarbeid blant kvinnelige russiske migranter i Finnmark, og korte historiske tilbakeblikk fra min egen og informantenes sovjetiske barndom. Analysen benytter dermed empiri både fra nåtid i Finnmark og en felles fortid i Sovjetunionen. Denne analytiske vekslingen i tid og rom bidrar til å sette empirien inn i en flerstedlig (Munkejord 2009) eller translokal sammenheng. 
Videre er det viktig å nevne at Finnmark er Norges nordligste fylke. Det har en utstrekning på $48637 \mathrm{~km}^{2}$ og en befolkning på bare 75758 (SSB: 2016). Finnmark representerer en spesielt interessant geografisk sammenheng for en slik empirisk studie både fordi det er en perifer og tynt befolket region og også fordi det grenser til Russland i øst og dermed utgjør et attraktivt bosetningsområde for russere, særlig for russiske kvinner. ${ }^{1}$ Russere utgjør den største innvandrergruppen i fem kommuner i Finnmark (Høydahl 2012).

Før jeg går nærmere inn på analysene, vil jeg diskutere de teoretiske begreper og perspektiver jeg anvender samt beskrive den metodiske fremgangsmåten denne studien bygger på.

\section{Fortellinger om sopp som translokale posisjoneringer}

I arbeidet med denne artikkelen har særlig Floya Anthias' (2007, 2008, 2013) begrep translokal posisjonering vært nyttig og inspirerende. Hun åpner opp for en rekke ulike former, nyanser og markører for sosiale posisjoneringer (2013: 133). Begrepet forstår dermed menneskers sosiale og translokale posisjoneringer som en stadig tilblivelsesprosess som tar form på og mellom konkrete steder, og dermed i og mellom kulturelle kontekster preget av bestemte majoritets- og minoritetsforståelser. Forstavelsen «trans» peker på kroppens tilknytninger på tvers av ulike geografiske, historiske, sosiale og emosjonelle rom (Anthias 2013: 131), eller som hun selv formulerer det $\mathrm{i}$ en annen sammenheng:

The concept of translocational positionality addresses issues of identity in terms of locations which are not fixed but are context, meaning and time related and which therefore involve shifts and contradictions. As an intersectional frame it moves away from the idea of given 'groups' or 'categories' of gender, ethnicity and class, which then intersect (a particular concern of some intersectionality frameworks), and instead pays much more attention to social locations and processes which are broader than those signaled by this. As such, the notion of translocational positionality attempts to address some of the difficulties found within intersectionality approaches and attempts to push the debate forward on theorising identity and belonging (Anthias 2008: 6).

Et viktig poeng i denne sammenhengen er at de nasjonale og kulturelle båndene ikke bare opererer innenfor migrantenes nasjonale tilknytninger, men også på tvers av nasjonale grenser og sosiale rom (2008: 15). Et slikt teoretisk fokus er ifølge Mathisen og Stenbacka (2015) egnet til å forskyve oppmerksomheten fra eksistensialistiske forestillinger om gruppetilhørighet, kultur, individ og nasjon. I stedet bidrar begrepet translokale posisjoneringer til perspektiver som deterritorialiserer, eller destabiliserer,

\footnotetext{
${ }^{1}$ Se også Mathisen (1998); Kramvig \& Stien (2002); Leontieva \& Sarsenov (2003); Flemmen (2007a, 2007b, 2008); Lotherington \& Fjørtoft (2007); Lotherington \& Flemmen (2007); Koukarenko (2007); Aure (2007, 2008, 2014); Kramvig \& Flemmen (2010); Johansen \& Olsen (2012, 2014); Viken \& Scwenke Fors (2014); Wara (2016); Wara \& Munkejord (2016) for en utdypende kontekstualisering av russere i Finnmark.
} 
sammenbindinger mellom mennesker og nasjonalstater. De foreslår det translokale perspektivet som en videreutvikling av teorien om transnasjonalitet:

Vi ser begrepet «translokalitet» som best egnet til å forklare lokale praksiser ettersom translokalitetsbegrepet er forankret i det lokale, samtidig som det fokuserer på nasjonale og globale prosessers samspill med og påvirkning på lokale virkninger (Mathisen \& Stenbacka 2015: 216).

Det translokale perspektivet gir således en ramme for å forstå tilhørighet som en pågående posisjonering hvor det stadig forhandler om steders betydning. I dette perspektivet handler tilhørighet ikke så mye om ens opprinnelsesland (å komme fra et bestemt sted på et bestemt tidspunkt), men heller om hvordan migranter skaper en følelse av tilhørighet til flere steder. Dette kan, i tråd med med Anthias, forstås som en "sammenfiltring» ${ }^{2}$ av ulike nettverk av steder, strukturer, relasjoner, engasjement, deltakelse, drømmer og anstrengelser både innenfor og på tvers av tid og rom (Anthias 2008: 17).

Kroppen som sted for translokale posisjoneringer

«Kroppen er sjelens fødested og støpeformen for ethvert annet eksisterende rom» (MerleauPonty 2000: 47).

Det er viktig å understreke at begrepet «translokal posisjonering» brukes i en fenomenologisk betydning av å bebo rom og tid, hvor nettopp bosted eller lokalisering ${ }^{3}$ knyttes til spørsmål om kroppsliggjøringsprosesser og persepsjon som alltid er intersubjektive (Merleau-Ponty 1994). Merleau-Ponty betrakter varen-i-verden som helhet, og den levde kroppen er alltid nærværende og samtidig både som subjekt og objekt: «Med kroppen er vi plassert i en historisk og gitt verden og på den samme måten er den erfarte verden sanset $\mathrm{i}$ vår bevissthet gjennom den levde kroppen» (Nortvedt 2008: 54). Dette har relevans for å forstå endringer i de russiske migrantenes intersubjektive rom som en kilde til å forstå kroppslige erfaringer (Flikke 2003: 209). Deres erfaringer fra Russland (i lys av sovjettiden) og fra Norge (som innvandrere) forstås her som en nedfelt, kroppsliggjort historie og som utstrakte prosesser, der kroppen er deres «innstilling i forhold til verden» (Csordas 1990: 8).

Denne kroppslige innstillingen, kan i tråd med Ahmed (2006) forstås både som objekter for og effekter av nærhet. Et slikt perspektiv innebærer tanken om at ulike aktiviteter og oppgaver blir kroppsliggjort gjennom repetisjoner og dermed danner grunnlag for vår oppmerksomhet. Den kroppslige nedfelte viten er således i interaksjon med den kulturelle og språklige verden (Merleau-Ponty 1994). Dette betyr at denne verden har sin bolig i kroppen, og at alle kroppslige erfaringer til sammen utgjør ens nedfelte intuisjon (1994). ${ }^{4}$ Hva kroppen «har en tendens til å gjøre» kan i et slikt

\footnotetext{
${ }^{2}$ Et lignende resonnement diskuteres i Berg m.fl. (2010: 11-37).

${ }^{3}$ Jamfør Merleau-Ponty (1994) forståelse av kroppen som er selv stedet og et utgangspunkt for erfaringen.

${ }^{4}$ Merleau-Ponty definerer det som den «primordial intensjonalitet» (1994: 81).
} 
perspektiv forstås som effekt av historie, snarere enn individuelle valg (Ahmed 2006). Dette innebærer at kulturelt betingede erfaringer forstås som en «horisontstruktur» eller en «naturlig» holdning til bestemte oppgaver (Merleau-Ponty 1994: 7). Ens horisont etablerer på denne måten et perspektiv (et synsfelt) som er strukturerende for hva en vil sanse og oppleve (Merleau-Ponty 2000: 16; Ahmed 2006: 547). MerleauPonty skriver: «Alt jeg ser, er prinsipielt innenfor min rekkevidde, i hvert fall innenfor min synsvidde, det er inntegnet på kartet over mitt 'jeg kan'» (2000: 16). Dette kroppsskjemaet «jeg kan», vil også aktualiseres i ulike reorienterings- og posisjoneringspraksiser, slik denne artikkelen vil vise.

I tråd med ovennevnte resonnement, vil innlemming av den levde kroppen i en lokalitet, eller det at en nykommer begynner å føle seg hjemme på et nytt sted, ikke bare handle om å bebo et allerede «endelig» sted. Heller trenger det nye bostedet seg inn i nykommerens sanser: Det definerer hva man lukter, hører, berører, føler, husker (Ahmed 1999). For å forstå migrantenes reorienterings- eller posisjoneringspraksis har således Ahmeds (1999) begrep «home-making» vært til nytte og inspirasjon, både forstått som «å føle seg hjemme» eller hvordan man noen ganger $i k k e$ klarer å føle seg hjemme (1999: 341). Videre forstås begrepet «å bebo» som å skape hjemlige relasjoner som gir «retninger av eksistens» (Douglas 1991: 290). Inspirert av disse perspektivene, vil denne artikkelen utforske russiske kvinners posisjoneringspraksis giennom en analyse av deres fortellinger om sopp.

\section{Metodologiske refleksjoner}

Min metodologiske tilnærming til fortellinger er inspirert av nyere perspektiver som binder narrative teorier sammen med symbolsk interaksjonisme (Järvinen 2005; Kristiansen 2015; Olsen 2015; De Fina \& Georgakopoulou 2008a, 2008b; Klausen m.fl. 2013; Gullestad 1996). Dette innebærer et fokus på fortellingers narrative innhold, men også på hvordan alle fortellinger er posisjonert i tid og rom. Det som blir sentralt for å forstå fortellinger som posisjoneringspraksiser «er at de skaper helhet og sammenheng ved at de gjennom aktiv handling knytter sammen ulike hendelser og kulturell kollektiv kunnskap» (Olsen 2014).

Datamaterialet er basert på feltarbeid utført i perioden 2012-2015. I denne artikkelen har jeg analysert data fra deltakende observasjon, fokusgruppeintervjuer og individuelle intervjuer. Jeg bruker her sitater fra fire av totalt 40 intervjuer, ett gruppeintervju og tre individuelle intervjuer (to av dem med samme informant), mens analysen også baserer seg på øvrige data som er samlet inn i forbindelse med studiet. I tillegg gjennomførte jeg som nevnt innledningsvis en sopptur med tre informanter da jeg ønsket å undersøke hvordan estetiske refleksjoner og praktisk kunnskap relatert til sopp ble praktisert blant russiske migranter i en norsk kontekst. Intervjuene foregikk på russisk og er blitt oversatt til norsk av forfatteren.

Jeg vil argumentere for at «sjangerkonvensjonen» (Gullestad 1996: 18) som kommer frem i de følgende utdragene kan forstås både som en meningsutveksling [i gruppeintervjuet] mellom meg og de tre kvinnene, og som en sosial posisjonering. Jeg analyserer således intervjusamtalene som aktive posisjoneringer som formes $\mathrm{i}$ en 
konkret kontekst der intervjueren er en medprodusent (Tanum \& Krogstad 2014: 256; Moldenæs 2006: 29). At jeg er russisk kvinne, som ble født på 70-tallet og som flyttet til Norge på 90-tallet, at jeg er skilt, gift på nytt og har to barn som er født i Norge, kan tenkes å ha innvirkning på datamaterialet som blir produsert. Som lytter og samtalepartner kan jeg ha påvirket informantene med kroppsspråk og ytringer som har styrt fortellingene i bestemte retninger (Moldenæs 2006: 29). I tillegg utgjør mine egne posisjoneringer, mine holdninger og forståelser av det fortalte en linse som jeg i mitt analysearbeid «har filtrert fortellingene gjennom» (Moldenæs 2006: 29). For eksempel lærte mine foreldre meg allerede i tidlig barndom at massemedia og samfunnet for øvrig var en gjenklang av våre partilederes stemmer (som var Brezjnev på den tiden), og at vi heller måtte lete etter «sannhet» hos våre respekterte skjønnlitterære forfattere. For forfatterne var i stand til å kamuflere budskap «mellom linjene». Dette har relevans for både hvordan jeg leser historie, aviser, litteratur og også for min egen forståelse av det fortalte den dag i dag. Merleau-Ponty sier at når gjenstander viser mer av noen sider enn av andre er det «fordi jeg selv befinder mig et bestemt sted, hvorfra jeg ser dem, men som jeg ikke kan se» (Merleau-Ponty 1994: 34). Ens ståsted som et perspektiv på verden må således forstås i sammenheng med den unike, mobile kroppen.

I neste avsnitt vil jeg gå nærmere inn på det som er problemstillingen i denne artikkelen, nemlig sopp som inntak til kvinnelige migranters posisjoneringspraksiser og som en fortelling om russiskhet i en norsk-sovjetisk kontekst.

\section{Høsting av sopp: Fysiologisk og mental næring}

«Sopp er en ekte russisk overlevelsestradisjon!» (Valentina, russisk kvinne bosatt i Norge)

Dette utdraget er hentet fra det første gruppeintervjuet ${ }^{5}$ jeg utførte med russiske kvinner som $\mathrm{i}$ dag bor $\mathrm{i}$ en liten nordnorsk by. Jeg var i den sammenheng invitert sammen med to andre informanter til Alina. Alina er i midten av 40-årene og flyttet til Norge på begynnelsen av 2000-tallet som utvekslingsstudent. I løpet av studietiden ble hun forelsket, giftet seg med sin norske utkårede, og bosatte seg etter hvert i Finnmark. Da intervjuet ble gjort, var Alina nybakt mor med barn nummer to. Valentina er rundt 40 år, og flyttet også til Finnmark på begynnelsen av 2000-tallet i forbindelse med studiene. Hun valgte å bli i Finnmark, fikk jobb og kjæreste og etter hvert to barn. Alina og Valentina har vært gode venner siden de kom til Finnmark. Svetlana er rundt 50 år, og flyttet som ekteskapsmigrant åtte år før intervjuet ble gjort. Hun har ingen barn, driver egen bedrift og har økonomiutdannelse fra Russland. Alina, som hadde invitert oss, åpnet samtalen med å si at hun syntes at det var «koselig å møtes for å

\footnotetext{
${ }^{5}$ Dette intervjuet ble gjort i desember 2012 da jeg var på min andre felttur. Informantene ble informert på forhånd om at intervjutemaet var «russisk tradisjonsforvaltning i Norge», og jeg informerte kort om at jeg både var interessert i hverdagslige praksiser og større begivenheter som hadde betydning for dem, særlig etter de hadde flyttet fra Russland til Norge.
} 
prate og erindre om Russland», særlig fordi hun var hjemme i forbindelse med fødselspermisjonen.

Vi møttes klokka tolv om formiddagen på en vanlig tirsdag. En deilig duft av bacalao ønsket oss velkommen, og middagsbordet var dekket med flere russiske retter, som russisk salat, syltete agurker og marinert sopp. Alina hadde selv stått for det meste, og vi andre var gledelig overrasket da vi ikke var forberedt på et slikt festmåltid.

1. Svetlana: Her møtes vi av den berømte russiske velkomsttradisjonen!

2. Valentina: Og ikke minst av at Alina vedlikeholder den!

3. Intervjuer: Nesten som å komme til Russland!

4. Svetlana: Imponerende, men hun er den huslige utgaven, og jeg tilhører de late. Det blir sjelden noe ekstra hjemme hos meg. Jeg ikke så særlig glad å lage mat, så mannen min har overtatt kjøkkenet.

5. Valentina: For en luksus! Du [til meg, Tatiana] har spurt oss om tradisjoner og se her er den mest tradisjonelle serveringen du kan ønske deg, takket være Alina som fortsatt vedlikeholder de ekte russiske overlevelsestradisjoner! Jeg elsker å plukke sopp, men jeg har aldri lært meg marineringsteknikker. Det er for de viderekommende og de ekstra flinke.

6. Svetlana: Jeg husker enda de tomme butikkhyllene [fra barndommen], det var vanskelig, men vi visste ikke bedre, så det var en normal tilstand, og det var likt for alle. Vi ble bare sterkere av det. Det var slik det var. Vi kunne ikke overleve uten sopp og bær, men det viktigste av alt var selve prosessen!

7. Alina: Men den viktigste næringen [når vi er på sopptur] er vel emosjonell næring og innlevelse!

8. Valentina: Enig, jeg kan gå timevis og beundre hver eneste sopp. Her i Norge er det få som plukker sopp, så du kan velge de fineste av de fineste. Og hver sopp har sin egen form og personlighet.

9. Alina: Det er nettopp det som er typisk russisk. Den russiske sjela som er dyrket på åndelige verdier.

10. Valentina: Raushet, gjestfrihet og pågangsmot. En ekte russisk kvinne kan lage mat av ingenting, eller som det sies: hun kan stoppe en galopperende hest og kan gå inn i et brennende hus [siterer den russiske dikteren Nikolaj Nekrasov].

11. Alina: Nettopp. Jeg tror at det er mest oppdragelse og ideologier som fremhever mental og åndelig næring, istedenfor fysiologisk næring.

12. Intervjuer: Hva mente du med det?

13. Svetlana: Heller si det rett ut, - propaganda heter det på norsk [med en spøkefull tone].

14. Alina: Jeg mente at ulike verdier kommer fra ulik oppdragelse. Det er annerledes å prate med en russer. Med nordmenn prater man ikke bare ulikt språk, men også ulik tematikk. Man spør ikke en russer om været og hva de har spist til middag. Det ville vært rart i en russisk kontekst. Man prater ikke bare generelt og om ingenting - om vær og vind, om praktiske gjøremål. Det er følelsesmessige tilstander og mellommenneskelig relasjoner vi er opptatt av, og det er opp til vedkommende man snakker med å svare på det eller ei. Jeg har inntrykk av at nordmenn ofte omtaler det praktiske eller det materielle, mens russere snakker om det emosjonelle. Vi russere går liksom rett på sak uten oppvarming.

Når Svetlana henviser til «den berømte russiske velkomsttradisjonen» (utsagn 1) gjennom Alina sin gjestfrihet, fortsetter Valentina med et innspill (utsagn 2), som posisjonerer Alina i et sett av privilegerte posisjoner både som ekte russisk, gjestfri og vertinne. Ettersom det hele skjer i Norge, kan «den russiske velkomsten» forstås i forhold til det norske, og Alinas individuelle gjestfrihet kan således kobles til en kollektiv fortelling om russiskhet. I utsagn 5 omtaler Valentina soppsanking som en 
«overlevelsestradisjon». Hun markerer sopp som noe «ekte russisk», samtidig som hun viser hengivenhet for marineringsteknikker. Igjen posisjoneres Alina som kulturbærer, samtidig som at soppen plasseres i en historisk kontekst. Metaforen overlevelsestradisjoner settes i relasjon til informantenes felles erindringer om matmangel og tomme butikkhyller i Sovjettiden. Soppen løftes videre opp og posisjoneres ikke bare som matauke, men også som mental næring i utsagnet «vi kunne ikke overleve uten sopp og bær, men det viktigste av alt var selve prosessen!» (utsagn 6), samt i utsagnet om sopp(turer) som «mental og åndelig næring» (utsagn 11). Sistnevnte uttalelse sier videre noe om hvilke viktige verdier som forhandles frem og verdsettes $\mathrm{i}$ informantenes felles fortelling om russiskhet.

Når Alina posisjoneres av Valentina ved hjelp av Nekrasovs poesi om en uredd, tapper, huslig og oppfinnsom «ekte russisk kvinne» (utsagn 10), reposisjonerer hun alle oss som er til stede rundt festbordet som «russiske kvinner» (utsagn 11). Utsagnet kan forstås som et resultat av en lengsel etter anerkjennelse for akkumulert kapital. ${ }^{6}$ Men det kan også forstås som kreative, dynamiske, kontekstavhengige og «pre-tildelte» posisjoner (De Fina \& Georgakopoulou 2008b: 278). I den sammenheng kan sitatet til Nekrasov leses som et trinn i Valentinas selvpresentasjon, der hun posisjoner seg selv som kulturbærer gjennom å framstå som en belest kvinne overfor oss andre som er til stede.

I utsagn 13 trekkes propaganda-begrepet inn som en forklaring på verdihierarkier. I utsagn 14 kobler Alina, i forlengelsen av dette, norske talemåter til «det praktiske og materielle» mens russiske talemåter blir fremstilt som «emosjonelle». Dette belyser både betydningen [verdiens plass] av emosjonalitet i fortellingen om russiskhet, men etablerer også en distinksjon mellom russiskhet og norskhet [oss og de andre].

\section{Fortellinger om soppen i lys av sovjettiden}

For å forstå hva som er på spill i samtalen over, og for å bedre kunne forklare hvordan det kan ha seg at informantenes fortellinger om marinert sopp bringer inn både historiske, moralske og kulturelle aspekter, vil jeg utdype noen minner fra mine informanters og min egen felles sovjetiske barndom.

Den første fortellingen vil giennom et kort historisk tilbakeblikk vise hvordan sopp er forankret i sovjetisk fattigdom og matmangel, mens den andre fortellingen har til hensikt å synliggiøre hvordan fortellinger om sopp kan forstås i lys av vår barndoms sovjetiske ideologier som la vekt på moral som fremhever verdier av «mental og åndelig næring» (Alina, utsagn 14).

«Vi kunne ikke overleve uten sopp» (Svetlana)

I kjølvannet av Oktoberrevolusjonen i 1917, og særlig i etterkant av 2. verdenskrig, satset den sovjetiske regjeringen på å bli en geopolitisk supermakt. Ett av de viktigste

\footnotetext{
${ }^{6}$ Kapitalene forstås her i tråd med Gullestad (1996) som utrykk for en strategi, snarere enn fastmønstret posisjon.
} 
satsningsområdene ble en industrialiseringsplan med hovedvekt på å bygge ut tungindustrien som var grunnlaget for militær opprustning (White 1979; Norman Waage 1990; Nistad 2004). Finansieringen av den kraftige industribyggingen samt frigjøringen av arbeidskraft for industrien gikk på bekostning av jordbruk og matproduksjon. Som del av denne politikken ble de selvstendige bøndene (kulakkene) utryddet og tvangskollektivisering gjennomført i en periode fra 1920årene til 1940-årene. Matmangel førte til innføring av et rasjoneringssystem og tomme butikkhyller ble etter hvert vanlig. Høsting av naturens gaver fikk dermed ikke bare en rekreasjonsmessig betydning, men utgjorde i tillegg en viktig kilde til ernæring. For de fleste russere i Sovjettiden ble soppsanking dermed en sentral høstaktivitet (Yamin-Pasternak 2008). En krukke med syltet eller marinert sopp fikk dessuten en tilsvarende rolle som en flaske vin, sjokolade eller blomster i dagens samfunn: en gave som kunne bringes til middagsselskap som en gest til vertskapet. Sopp kunne brukes både til hverdag og fest, og kunne ikke minst gis til en venn som takk for en tjeneste.

\section{«Vi var barn av Sovjet» (Natalja)}

Det klasseløse samfunn, institusjonalisering og indoktrinering, var kjennetegn ved det totalitære sovjetiske regimet. Sovjetunionen var bygd på marxistiske teorier som ble videreutviklet av Lenin, og er kjent i Russland som den marxistisk-leninistiske ideologien. KPSS ${ }^{7}$ var det eneste partiet i det sovjetiske regimet. Alle aspekter ved sosialt liv, fra politisk engasjement og religion til familieliv, barneoppdragelse og fritidsaktiviteter ble regnet som statens ansvarsområder (White 1978: 38). Store ressurser ble brukt for å utforme «den nye bevisstheten» (Lenin 1950: 5).

Som Natalja, en av mine informanter, uttrykte det: «Vi var barn av Sovjet». Og som barn og ungdom var vi også den prioriterte gruppen i kampen for den sovjetiske «ærbare bevissthet». Heldagsåpne barnehager, seksdagers skoler og organiserte fritidsaktiviteter ble tilrettelagt og overlatt til statlige institusjoner, noe som resulterte $\mathrm{i}$ at foreldrene fikk lite felles tid med sine barn, og vi med våre foreldre.

I syvårsalderen ble vi medlemmer av partiets barneorganisasjon (Oktjabrjata), i tiårsalderen medlemmer av Pionerene, og senere, i 14-15 årsalderen, ble de fleste av oss medlemmer i Komsomol ${ }^{8}$ (Ungkommunistforbundet). Komsomol skulle være et viktig bindeledd mellom det sovjetiske kommunistpartiet og massene. Medlemskap i Komsomol var «frivillig», men uten det var det vanskelig å få egen leilighet, da alle leiligheter var statseide og dermed først ble fordelt i henhold til politisk lydighet og deretter behov, som blant annet familiestørrelse. Uten medlemskap var det også

\footnotetext{
${ }^{7}$ Kommunistitjeskaja Partija Sovetskogo Sojuza.

${ }^{8}$ Komsomol (VLKSM Vsesojuznyj Leninskij Kommunistititsjeskij Sojuz Molodjozji) ble opprettet i 1918. Det skulle være en uavhengig ungdomsorganisasjon, men solidarisk med Kommunistpartiet. På slutten av 70-tallet hadde partiet rundt 34 millioner medlemmer og rundt 4500 heltidsansatte sekretærer som jobbet med ideologisk arbeid (Remington 1988:42). Opptaksintervjuene i forbindelsen med medlemskap var utført av en spesiell opptaksnemd. Komsomol-medlemmenes rolle var å formidle partiets budskap, overbevise, agitere, forsvare sosialistisk politikk og kritisere motstandere.
} 
vanskelig å få en attraktiv jobb eller studieplass på universitetet (medlemsbevis var et obligatorisk vedlegg til søknad). Medlemskap i de ulike aldersbestemte organisasjonene forutsatte en muntlig eksaminering om Lenins og andre prominente personers biografier, om partiets suverene ideologi og om Sovjetunionens historie, overlegenhet og lysende framtid. Ved inntredelse i barneorganisasjonen underskrev vi en erklæring om å være trofast, følge opp og videreføre partiets politiske ideer. Fra sjette til tiende klasse hadde vi obligatorisk undervisning i militært forsvar for både jenter og gutter, der vi lærte å lese kart, marsjere, demontere våpen (kalasjnikov), skyte, og vi hadde også andre fysiske øvelser som ble ansett som viktige for den sovjetiske borgerens fysiske og psykiske helse. I tillegg organiserte Pionerene alt fra høytidelige politiske kampanjer og solidaritetsmøter, til speiderleirer der barna fikk undervisning i militære ferdigheter.

Dette historiske tilbakeblikket viser hvordan både mine egne og informantenes posisjoneringspraksiser som innvandrere $\mathrm{i}$ Nord-Norge kan belyses gjennom våre felles barndomserfaringer forstått som en forlengelse av den sovjetiske kroppen (Merleau-Ponty 1994). I det følgende vil jeg i så måte diskutere fortellinger om sopp som et translokalt uttrykk for russiskhet. Mer konkret viser analysen at fortellinger om sopp kan forstås som et inntak til følelser, og derigjennom som en metafor for russiskhet i Finnmark.

\section{Fortellinger om sopp som praktisering av følelser}

I dette avsnittet vil jeg vise hvordan følelser «arbeider» og fortelles fram, samt hvordan følelsesrepertoaret praktiseres i hverdagslige samtaler om sopp. Dette kan forklare romantiseringen av det emosjonelle som Alina kommenterer i gruppeintervjuet over (utsagn 14). Dette fokuset giør det mulig å påpeke at følelser som «erfaringslatente horisonter» (Merleau-Ponty 1994: 34-35) representerer stabile strukturer i en translokal væren-i-verden. Det at følelser hos Merleau-Ponty er en psykososial dimensjon som har sin forankring i en erfart og levd kropp, betyr at følelser relateres direkte til sosiale prosesser. Ulike måter å uttrykke følelser kan dermed sies å produsere kontinuitet i kulturelle eller sosiale rom.

Alina sitt utsagn viser at følelser er viktige for mine russiske kvinnelige informanter for å forstå forhandlinger om tilhørighet i hverdagen. Alina refererer $\mathrm{i}$ forlengelsen av dette til samtaleemner som ekskluderer mellommenneskelige relasjoner i en norsk kontekst. Alina snakker om emosjonalitet, ikke som en psykologisk disposisjon, men som en sosial dimensjon som er relatert til hennes sovjetiske barndom: «dyrket på åndelig verdier».

For å klargjøre Alinas ytring om «følelser» vil jeg bruke et utdrag fra et annet oppfølgingsintervju. I dette tilfellet er det Olga som på telefon utdyper sine tanker om soppraksiser. ${ }^{9}$ Hun fortalte blant annet at for henne er soppturer mest for rekreasjon:

\footnotetext{
${ }^{9}$ Dette utsagnet ble ikke tatt opp på bånd, men ble notert så ordrett som mulig i løpet av og like i etterkant av vår telefonsamtale.
} 
«Det er selve opplevelsen og anledningen til å vandre alene i skogen jeg setter pris på». Olga forteller videre:

Det er nettopp den russiske emosjonaliteten som er viktig å belyse for å forstå den russiske mentaliteten. Ikke bare som en del av oppdragelse og sovjetisk oppfostring, men først og fremst som praktisering av følelser i ulike kontekster. Vi diskuterer følelser og vi reflekterer over følelser. Og ikke minst praktiserer vi dem. Vi praktiserer følelser i den forstand at vi bruker dem i hverdager og i fest. Og vi gjør oss kjent med eget følelsesspekter og våre reaksjoner. Følelser er naturlig, ikke bare som en indre tilstand, men også som samtaleemne, på lik linje med fakta og dagligdagse ting. I Norge gis det veldig lite plass til følelser. Jeg mener ikke at nordmenn ikke har følelser, men heller at følelser blir underkommunisert i Norge.

Olga reflekterer rundt «følelser» som en viktig del av den russiske mentaliteten, delvis som en konsekvens av det sovjetiske systemet, men først og fremst som en modalitet av erfaringer som kommer gjennom innøving, repetisjon og gjentagelse, for eksempel når man plukker sopp, rensker sopp, foredler eller nyter sopp i fellesskap eller alene. Gjennom gjentakelse, mener Olga, kan en lære seg både å utrykke og å håndtere følelser og derigjennom styrke også ens egenverd og psykiske helse. Videre, på lik linje med flere andre av mine informanter, referer hun til den store fortellingen om at følelser i Norge er «underkommunisert» og at det gis «veldig lite plass til følelser».

Olgas refleksjon rundt følelser som en dagligdags praksis og om hvordan samtaler om følelser ikke passer inn i en norsk kontekst, har en overføringsverdi til det som Anthias kaller «inter-relaterte problemstillinger rundt grenser og hierarkier av tilhørighet» (2008: 6). Det å samtale om følelser kan således forstås både som et uttrykk for savnet tilhørighet, som et uttrykk for en diasporisk romantisering av emosjonalitet som symbol på russiskhet og som uttrykk for en mestringsstrategi $i$ en mer grunnleggende, eksistensiell forstand. Vi ser videre hvordan russiske og norske verdier markeres og fortelles fram. Olga gir følelser en «naturlig» plass som samtaleemne «på lik linje med fakta». Distinksjonen mellom «fakta» versus «følelser» kan tolkes som en allegorisk anvendelse i framstilling av den vestlige kapitalistiske og materialistiske mentalitet, i kontrast til den sosialistiske ideen om høy moralsk og «ren kommunistisk bevissthet» (jfr. Lenin 1950). Samtidig kan påstanden om at det «i Norge gis det veldig lite plass til følelser» relateres til bestemte «norske» måter å bruke rommet på. Det å skape rom for å kunne utrykke følelser fortelles her i betydningen av å utvide det norske rom. Dermed forskyves oppmerksomheten fra eksistensialistiske forestillinger om russiskhet som gruppetilhørighet til spørsmål om (trans)lokal tilknytning gjennom kroppen som erfaringsutgangspunkt (Merleau-Ponty 1994).

\section{Om soppen som kunne snakke: Fantasi, kreativitet og poesi som overlevelsespraksis}

I det følgende vil jeg gjengi et utdrag fra et av de individuelle intervjuene hvor jeg ba informantene om å fortelle om naturopplevelser og assosiasjoner knyttet til natur. Intervjuet ble gjennomført hjemme hos Natalja: 
Jeg elsket høsten som barn, med mange fine farger og soppturer med foreldrene mine. Det var en veldig naturlig, men samtidig oppstemt stemning [når vi skulle på sopptur]. Vi hadde ikke bil og måtte avtale på forhånd med andre som kunne kjøre oss. Det var få som hadde bil på den tiden, så en biltur i seg selv var et høydepunkt. Jeg plukket sopp i en egen kurv, jeg lekte med dem og snakket med dem. Jeg levde meg inn i naturen og høstfargene slik at soppen for meg ikke bare var sopp; den kunne snakke og fortelle sin skogshistorie. Noen ganger tenkte jeg på Rødhette, som var på vei til bestemor, og jeg forestilte meg at soppene var dvergene fra eventyret om Snøhvit som kunne komme og berge meg fra ulven i Rødhette. Og så var det sopprensking da vi kom hjem. Da levde soppene ikke lenger, slik de hadde gjort i skogen. Så ulogisk som barn tenker, og så impulsivt! Det er fargene jeg husker best. Helt tydelig. Og lukten. Foreldrene mine, særlig mamma, brukte å renske og kontrollere soppen. Da var hun i hvert fall til stede og glad. Som oftest var alt i kurven spiselig.

Soppsanking var en naturlig og hyggelig aktivitet som ble introdusert for Natalja fra småbarnsalderen. Hun forteller om sopp som levende vesener og eventyrskikkelser: Rødskrubben var Rødhette, steinsoppen var Snøhvit. Dette kan leses ikke bare som et uttrykk for barnet Natalja og hennes unike fantasiverden, men også som et uttrykk for en «kreativ involvering i tid og rom» (Ingold 2000). Dermed illustrerer eksempelet også hvordan opplevelser som skrives inn i vårt sanseapparat senere kan brukes til å gjenkjenne forskjellige sopper i landskapet. På den ene siden ser vi at Natalja oppdager mening i sine egne omgivelser gjennom å ta disse i bruk (Kramvig 2006: 159). Samtidig ser vi at en intertekstuell kobling gjøres til andre store fortellinger (Olsen 2015). Det vil si at Nataljas intime stemme kobles til en større soppfortelling som inneholder flere stemmer. For å gripe dynamikken i Nataljas meningskonstruksjon rundt sopp, og hvordan ulike former for makt er knyttet til denne, er det viktig, ifølge Anthias (2008), å relatere de ulike posisjoneringene på ulike nivå og $\mathrm{i}$ ulike sammenheng med både det forestilte og det fortalte.

Nataljas soppfortelling kan på individnivå leses som et uttrykk for et savn i en mor-barn-relasjon, der hun søker trøst og anerkjennelse i naturen, istedenfor hos mor. Dette kan forklares med bakgrunn i at Natalja opplevde at hennes mor var psykisk ustabil og plaget med lange og tunge depresjoner. Dette kan være en av grunnene til at Natalja valgte å fortelle om barndommens soppturer som øyeblikk med en mor som var preget av glede og tilstedeværelse. Det at Natalja hadde en rik fantasi og innlevelsesevne kan forstås som en håndteringsstrategi, det vil si at hun kompenserte for mangelfull omsorg fra sin mor gjennom å skape et fullkomment eventyr når hun var på sopptur $i$ skogen. Samtidig, når maktens stemme tas inn $i$ fortellingen, ser vi at mor-barn relasjonen normaliseres til en naturlig sovjetisk oppdragelsessituasjon. Som Gorbatsjov oppsummerer det i Perestrojka:

Vi har oppdaget at mange av problemene når det gjelder barns og ungdoms oppførsel, i vår moral, kultur og produksjon, delvis er forårsaket av svekkede familiebånd og en slapp holdning til familiens ansvar for sine (Gorbatsjov 1988: 118).

Det som interesserer meg i denne sammenhengen er hvordan fortellinger om sopp transformerer tid og rom for således å etablere et nytt «hjem» hvor hjerte og tanker bor (Merleau-Ponty 2000: 47). «Hjemmet» i denne sammenheng, kan forstås som å 
handle om det å kjenne fortrolighet og gjenkjennelse på et nytt sted på en slik måte at man kjenner at det er integrert i kroppsskjemaet «jeg kan» (Merleau-Ponty 2000: 16; Simonsen 2005: 131).

Jeg vil i det følgende argumentere for at Nataljas innlevelsesevne er av både personlig og kollektiv karakter. I et senere intervju fortalte Natalja at hun fortsatt $i$ dag bruker naturen til å skape sin egen eventyrverden. Hun forteller:

Det er viktig å kunne skape en indre verden. For å kunne smelte sammen med
soppverdenen må man tenke som en sopp, og gi farge til den fargeløse verden med vakre
opplevelser. Når jeg var barn så trodde jeg på Lenin og var veldig stolt av å bære Lenins
tradisjoner og hans «eventyr». Vi er barn av Sovjet og er oppdratt med eventyr og
litteratur. Som det heter i den sangen: «Min adresse er hverken hus eller gate, min
adresse er Sovjetskij Sojuz [Sovjetunionen]» [latter].

Natalja tar erindringer om Lenin inn i sin fortelling, og posisjonerer sin personlige barndomsfortelling i en sovjetisk kontekst gjennom utsagnet «vi er barn av Sovjet».

Selv om Natalja i utgangspunktet forteller om en konkret praksis, nemlig det «å høste sopp» eller «å være på sopptur i skogen», refererer hun til opplevelser som er direkte relatert til kroppsliggjorte verdier av sted som en forlengelse av den sovjetiske kroppen. Eksempelet viser hvordan kulturelle ideer, metaforer og begreper fra den litterære og poetiske verden kan brukes av informantene «som en kilde til selvforståelse og et middel til å strukturere de fortellingene som skaper denne selvforståelse (...), ikke som 'regler', men som organiserende begreper som stadig skapes og gjenskapes av aktører» (Gullestad 1996: 27). Dette betyr at individer eller grupper som lever innenfor bestemte kulturelle, sosiale eller politiske hegemoniske systemer, trekker veksler på elementer fra disse repertoarene for å skape mening $\mathrm{i}$ sine liv (ibid.: 31 ).

Natalja tar Lenins stemme inn i sin fortelling, og bringer den fra det personlige til det kollektive giennom utsagnet «vi er barn av Sovjet». Det viser at soppfortellinger er meningsmettet og formidler flere budskap, både direkte og indirekte. I den indirekte fortellingen plasserer Natalja soppsanking, sine egne eventyr, leninisme, og klassisk litteratur i en likeverdig sammenheng. Deretter harselerer hun med den sovjetiske optimisme ved å referere til et sitat fra en kjent sovjetisk sang: Min adresse er hverken hus eller gate, min adresse er Sovjetskij Sojuz [Sovjetunionen]. Nataljas historie illustrerer således hvordan fortellingen om sopp fungerer som posisjonering «i

Nataljas allegoriske språkbruk ${ }^{10}$ kan dermed tolkes både på et konkret eksplisitt nivå som handler om sopp som matauke, fest og barndomsopplevelser, men også på et indirekte, abstrakt og underliggende nivå, som bringer fram den politiske stemmen fra hennes sovjetiske barndom. På den måten ser vi at fortellinger om sopp kan fungere som kamuflasje (å si noe gjennom noe annet) og som en motstrategi mot sovjetiske entydige ideologier.

\footnotetext{
${ }^{10}$ Se også Ridderstrøm (2016: 1-2).
} 


\section{Konklusjon}

Gjennom en historisk og kulturforankret analyse av fortellinger om sopp viser artikkelen hvordan sopp som meningsmettet fenomen kan brukes til å gjenskape russiske rom i Finnmark. Når russiske kvinner snakker om betydningen av å skape rom for å kunne utrykke følelser, ser vi at sopp ikke bare representerer godt russisk vertskap i festlig lag, men også en måte for dem å uttrykke og reflektere rundt (trans)lokal tilknytning. Med tilknytning i denne artikkelen menes ikke russiske kvinner gjennom eksistensialistiske forestillinger om gruppetilhørighet, men heller hvordan den russiske «væren-i-verden» reflekteres og transformeres og derigjennom skaper forbindelser til både en russisk og en norsk kontekst. Artikkelen viser videre hvordan informantenes «små fortellinger» er situert $\mathrm{i}$ forhold til den «store fortellingen» fra deres sovjetiske barndom, og også hvordan de små fortellingene representerer et posisjoneringsarbeid og en reorganisering av både implisitt [nedfelt] og eksplisitt kunnskap (De Fina \& Georgakopoulou 2008a: 379).

Et viktig poeng er at ettersom identifikasjonsprosesser i sovjettiden ble definert gjennom «det klasseløse samfunn» som en felles kollektiv identitet, danner dette et behov hos de russiske migrantene for å skape alternative markører for klassedistinksjon. Dette skjer, som artikkelen viser, gjennom blant annet bruk av et rikt, blomstrende språk, gjennom referanser til russisk poesi og litteratur, samt gjennom fremvisning av «ekte vertinneskap» når russiske venninner samles. Informantenes kulturspesifikke fortellingssjanger kan således forstås som en orienteringsramme og som et utrykk for at de besitter en spesiell kunnskap som i neste omgang bidrar til at de kan skape seg et eget russisk rom og tilhørighet i Nord-Norge.

Migrantenes posisjoneringspraksiser er følsomme for mange modaliteter som forbinder barndommens Sovjet og nåtidens Finnmark gjennom deres unike, men samtidig felles og nedfelte måte å være-i-verden på. Artikkelen viser således relevansen av et translokalt perspektiv for å forstå hvordan fortellinger om sopp i en norsk-russisk sammenheng kan forstås som uferdige, og aktive (re)posisjoneringer. Fortellinger om soppturer som tradisjonspraksiser referer i så måte ikke bare til «sopp» som en næringsgivende og viltvoksende vekst, men representerer også forhandlinger om tilhørighet i tid og rom som må forstås i en større geopolitisk og kulturell kontekst.

\section{Om artikkelen}

Jeg vil gjerne takke professor Mai Camilla Munkejord, professor Halldis Valestrand og førsteamanuensis Sissel Eriksen for gode kommentarer til et tidligere utkast av denne artikkelen. Jeg vil også takke medlemmene i FRISAM-prosjektet Mobile Lifestyles ledet av professor Siri Gerrard, forskningsgruppen Sted, Makt og Mobilitet, samt Narrativeforskningsgruppen ved UiT, NAU for inspirasjon underveis i arbeidet med denne teksten. Jeg vil dessuten få takke de anonyme fagfellene og redaksjonen i Nordisk Østforum for gode kommentarer. 


\section{Referanser}

Ahmed, Sara (1999) «Home and Away: Narratives of Migration and Estrangement». International fournal of Cultural Studies 2 (3): 329-347.

Ahmed, Sara (2006) «Orientations: Toward a Queer Phenomenology». Fournal of Lesbian and Gay Studies 12 (4): 543-574.

Anthias, Floya (2013) «Hierarchies of Social Location, Class and Intersectionality: Towards a Translocational Frame». International Sociology 28 (1): 121-138.

Anthias, Floya (2008) «Thinking Through the Lens of Translocational Positionality: an Intersectionality Frame for Understanding Identity and Belonging». Translocations: Migration and Social Change 4 (1): 5-20.

Aure, Marit (2007) «Migrasjonskanaler og rekrutteringsprosesser: Å bli arbeidsmigrant». Sosiologi $i$ dag 37 (3-4): 9-29.

Aure, Marit (2008) Arbeidsmigrasjon frå Teriberka til Båtsfjord 1999-2002. Dr.phil.-avhandling. Tromsø: Universitetet i Tromsø.

Aure, Marit (2014) «Grensemangfold i arbeid og endring» i Arvid Viken \& Bjarge Schwenke Fors (red.) Grenseliv. Stamsund: Orkana Akademisk Forlag (113-129).

Berg, Anne-Jorunn, Berit Gullikstad \& Anne Britt Flemmen (2010) Likestilte norskheter: om kjønn og etnisiteter. Oslo: Fagbokforlaget.

Csordas, Thomas (1990) «Embodiment as a Paradigm for Anthropology». Ethos 18 (1): 5-47.

De Fina, Anna \& Alexandra Georgakopoulou (2008a) «Analysing Narratives as Practices». Qualitative Research 8 (3): 379-387.

De Fina, Anna \& Alexandra Georgakopoulou(2008b) «Introduction: Narrative Analysis in the Shift from Texts to Practices». Text $\mathcal{E}$ Talk - An Interdisciplinary fournal of Language. Discourse Communication Studies 28 (3): 275-281.

Douglas, Mary (1991) «The Idea of a Home: A Kind of Space». Social Research 58 (1): 287-307.

Etkind, Alexander (1996) «Psychological Culture» i Dmitri Shalin (red.) Russian Culture at the Crossroads. Boulder: Westview Press (99-125).

Flemmen, Anne Britt (2008) «Transnational Marriages - Empirical Complexities and Conceptual Challenges. An Exploration of Intersectionality». Nora. Nordic fournal of Feminist and Gender Research 16 (2): 114-129.

Flemmen, Anne Britt (2007a) «Det er lett å være mannfolk i lag med Elena. Norske menn om kjønn og nasjonalitet i russisk-norske ekteskap» i Anne Marit Haugan (red.) Maskuliniteter $i$ Nord. Tromsø: Kvinnforsk, Universitetet i Tromsø (111-127).

Flemmen, Anne Britt (2007b) «Russiske kvinner i nordnorske aviser - minoritets- og majoritetskonstruksjoner». Tidsskrift for kjønnsforskning 31 (1): 37-54.

Flikke, Rune (2003) «Kroppsliggjøring, feltarbeid og okkulte erfaringer». Norsk Antropologisk Tidsskrift 4 (14): 207-220.

Gorbatsjov, Mikhail (1988) Perestrojka. Nytenkning for vårt land og verden. Oslo: Hjemmets bokforlag.

Gullestad, Marianne (1996) Hverdagsflosofer: Verdier, selvforståelse og samfunnssyn $i$ det moderne Norge. Oslo: Universitetsforlaget.

Høydahl, Even (2012) «Innvandreres bosettingsmønster». Tilgjengelig på www.ssb.no/befolkning/artikler-ogpublikasjoner/innvandrere-i-bygd-og-by. Lesedato 07. juli 2016.

Ingold, Tim (2000) The Perception of the Environment. Essays on Livelihood, Dwelling and Skill. London and New York: Rouledge (1-7).

Järvinen, Margaretha \& Nanna Mik-Meyer (red.) (2005) Kvalitative metoder $i$ et interaktionistisk perspektiv. Interview, observationer og dokumenter. 1. utg., 3. oppl. København: Hans Reitzels Forlag.

Johanson, Lisbeth \& Kjell Olsen (2014) «Grensekryssing - Studieutveksling som springbrett ut i den store verden?» i Arvid Viken \& Bjarge Schwenke Fors (red.) Grenseliv. Stamsund: Orkana Akademisk Forlag (71-83).

Johanson, Lisbeth \& Kjell Olsen (2012) «Livsstilsmigrasjon i nordområdene». Nordisk Østforum 26 (2): 155-175.

Klausen, Rita, Haugsgjerd, Svein \& Geir, Fagerjord Lorem (2013) "'The Lady in the Coffin'- Delusions and Hearing Voices: A Narrative Performance of Insight». Qualitative Inquiry 19 (6): 431-440.

Koukarenko, Natalia (2007) «Normative Masculinities and Men's Practices in Russia» i Anne Marit Haugan (red.) Maskuliniteter $i$ nord. Tromsø: Kvinnforsk, Universitetet i Tromsø (97-111). 
Kristiansen, Guro Korsnes (2015) «Hjemme- og lønnsarbeidets mening og verdi. Norske pars fortellinger om det å kjøpe private husholds- og omsorgstjenester». Tidsskrift for kjønnsforskning 39 (3-4): 204-223.

Kramvig, Britt (2005) Fleksible «kategorier, fleksible liv». Norsk antropologisk tidsskrift 16 (2-3): 97-108.

Kramvig, Britt \& Anne Britt Flemmen (2010) «Mangfold, likhet og likestilling i Sápmi» i Anne-Jorunn Berg, Anne Britt Flemmen \& Berit Gullikstad (red.) Likestilte norskheter: Om kjønn og etnisitet. Trondheim: Tapir Akademisk Forlag (167-195).

Kramvig, Britt \& Kirsten Stien (2002) Grenseløs verdighet? Alta: Rapport nr. 7/02. Finnmark: NORUT.

Lenin, Vladimir Iljitsj (1950) Sotsjinenija. 4 bind. Leningrad: Gosudarstvennoe izdatelstvo polititsjeskoj literatury.

Leontieva, Alexandra \& Karin Sarsenov (2003) «Russiske kvinner i skandinaviske medier». Kvinneforskning 27 (2): $17-30$.

Lotherington, Ann Therese \& Anne Britt Flemmen (2007) «Ekteskapsmigrasjon i det norske maktfeltet». Sosiologi i dag 37 (3-4): 58-82.

Lotherington, Ann Therese \& Kjersti Fjørtoft (2007) «Capabilities and Participation: Russian Women in North» i Bjørn Hvinden \& Håkan Johansson (red.) Citizenship in Nordic Welfare States: Dynamics of Choice, Duties and Participation in a Changing Europe. London og New York: Routledge (112-125).

Lotherington, Ann Therese (2008) «Over grensen: Konstruksjoner av likestilling og norskhet i russisk-norske familier». Tidsskrift for kjønnsforskning 32 (1): 6-20.

Mathisen Tina \& Susanne Stenbacka (2015) «Unge migranter skaper steder: translokale og lokale praksiser i rurale områder i Norge og Sverge» i Marit Aure, Nina Gunnerud Berg, Jørn Cruickshank \& Britt Dale (red.) Med sans for sted. Nyere teorier. Bergen: Fagbokforlaget (213-229).

Mathisen, Stein Roar (1998) «Det farlige naboskapet i nord: Eksplisitte og implisitte fortellinger på en 'ny' grense». Tradisjon 28 (2): 11-23.

Merleau-Ponty, Maurice (1994) Kroppens fenomenologi. København: Pax Forlag.

Merleau-Ponty, Maurice (2000) Øyet og ånden. Oslo: Pax.

Moldenæs, Turid (2006) I sitt bilde? Identitet og identitetskonstruksjon i lokalsamfunn. Trondheim: Tapir Akademisk Forlag.

Munkejord, Mai Camilla (2009) Hjemme $i$ nord. En analyse av stedsopplevelser med utganspunkt $i$ kvinnelige og mannlige innflytters fortellinger om hverdagsliv $i$ Havøysund og Vadsø, Finnmark. Tromsø: Avhandling for graden Philosophiae Doctor, Det samfunnsvitenskapelige fakultet, Institutt for planlegging og lokalsamfunnsforskning.

Nistad, Bjørn (2004) Russisk politisk idehistorie fra opplysningstiden til $i$ dag. Oslo: Solum Forlag AS.

Nortvedt, Finn (2008) «Kroppsfenomenologisk forskning: I grenselandet mellom empiri og filosofi». Vård $i$ Norden 8 (3): 53-55.

Olsen, Kjell (2010) Identities, Ethnicities and Borderzones. Examples from Finnmark, Northern Norway. Stamsund: Orkana Akademisk.

Olsen, Kjell (2014) «Kjønnsbetingede grensefortellinger» i Arvid Viken \& Bjarge Schwenke Fors (red.) Grenseliv. Stamsund: Orkana Akademisk Forlag (129-145).

Remington, Thomas (1988) The Truth of Authority. Pittsburgh: University of Pittsburgh Press.

Ridderstrøm, Helge (2016) «Allegori» i Bibliotekarstudentens nettleksikon om litteratur og medier (1-27).

Simonsen, Kirsten (2005) Byens mange ansigter - konstruktion af byen $i$ praksis og fortelling. 1.utg. Roskilde: Roskilde Universitetsforlag.

SSB (2016) «Folkemengde og befolkningsendringar, 1. kvartal». Tilgjengelig på www.ssb.no/befolkning/ statistikker/folkemengde/kvartal/2016-05-12?fane=tabell\&tabell=265361 Lesedato 21. juli 2016.

Tanum, Sofie \& Anne Krogstad (2014) «Fortellinger om livet uten arbeid». Sosiologisk tidsskrift 3 (22): 249-275.

Viken, Arvid \& Bjarge Schwenke Fors (red.) (2014) Grenseliv. Stamsund: Orkana Akademisk Forlag.

Wara, Tatiana \& Mai Camilla Munkejord (2016) «Naturen som rekreasjon og heteroseksuell romantikk: En studie av russiske kvinnelige migranters poetiske fortellinger om natur og kjønn». Norsk Antropologisk Tidsskrift 27 (1): 22-38.

Wara, Tatiana (2016) «Kvinner og klær - En fenomenologisk analyse av hvordan russiske kvinner 'kler seg' for å passe inn på et nordnorsk sted». Sosiologisk tidsskrift 24 (2): 101-122.

Wara, Tatiana (2009) «Mitt norske Russland. Brudd og kontinuitet $i$ identitetsforvaltning». Masteroppgave i pedagogikk. Tromsø: Universitetet i Tromsø.

White, Stephen (1979) Political Culture and Soviet Politics. London: Macmillan Press.

Yamin-Pasternak, Sveta (2008) «From Disgust to Desire: Changing Attitudes toward Beringian Mushrooms». Economic Botany 62 (3): 214-222. 